\title{
DOES TAX EVASION SIGNIFICANTLY CONTRIBUTE TO OVERALL ECONOMIC CRIME IN SERBIA?
}

\author{
Goranka Knežević1*, \\ Vladan Pavlović, \\ Kıvanç Halil Arıç3 \\ ${ }^{1}$ Singidunum University, \\ Belgrade, Serbia \\ 2University of Pristina - \\ K. Mitrovica, \\ Faculty of Economics, \\ K. Mitrovica, Serbia \\ ${ }^{3}$ Sivas Cumhuriyet University, \\ Faculty of Economics and \\ Administrative Sciences, \\ Department of International \\ Trade and Logistics, \\ Turkey
}

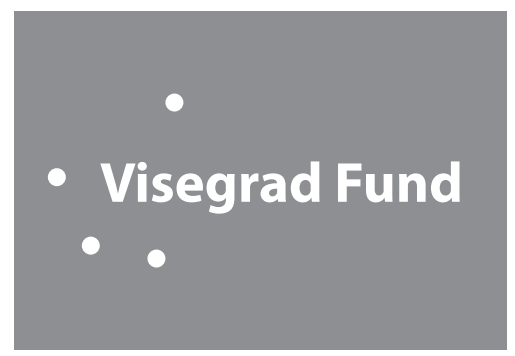

Correspondence:

Goranka Knežević

e-mail:

gknezevic@signidunum.ac.rs

\begin{abstract}
:
Tax evasion is one of the main types of economic crime conducted by entities and individuals. We have shown that number of individuals prosecuted for tax evasion contributed in 2014 with $28.67 \%$ of total prosecuted economic crime acts, and then it rose to $57.45 \%$ in the year 2018 . That implies that the tax modernization project which covers the period from 2018 to 2023 is a project of great importance.
\end{abstract}

Keywords:

tax evasion, economic crime.

\section{INTRODUCTION}

At the global level economic fraud cost the economy 3.6 billion US \$ (ACFE,2020). Among economic crime, tax evasion is one of the main types of crime conducted by entities and individuals. In this article, we will focus on entities' tax evasion. Tax evasion is one of the main problems in transition economies influencing not only governmental revenue and budget but also governmental spending and it raises inequality between honest taxpayers and tax evaders. In terms of not being caught tax evaders are exposed to low risk and high return in comparison with the honest taxpayers. Many researchers show interest in tax evasion trying to determine factors that influence it (Abdixhiku, 2013). There are micro and macro factors influencing tax evasion. Among macro factors, there are tax rates, tax structure, tax system, country general macroeconomic factors such as inflation, corruption level, political system, the legal system, and the possibility of individuals and firms to be detected. Among micro factors tax, morale, firm characteristics, profitability, leverage, capital intensity ratio, and other factors influence firms to evade taxes. In Serbia, as a transition economy, many factors influence tax evasion. Savić, Dragojlović, Vujošević, Arsić and Martić (2015) show that in 18 European countries including Serbia the efficiency of tax administration affects tax evasion. The main goal of this research is to investigate the influence of the number of employees in tax administration and employment rate on the grey economy level. The assumption is that an increase in the total number of employees in the tax administration will have a negative impact on the level of the grey economy. Ranđelović (2014) provides evidence on the impact of the change in income tax rates and the degree of its progressiveness on the scale of labor tax evasion in Serbia. Evading payroll taxes in Serbia are quite a common scheme of tax evasion. Our research was built on the theoretical assumption that the higher is the ability of being caught more efficient is the tax system. 
If there are more individuals prosecuted the better are legal rules and law enforcement system implying a higher probability of being caught for tax evasion.

To develop this idea, our paper is structured as follows. Firstly, economic crime and tax evasion are defined contextually. After that, we developed an extensive literature review regarding tax evasion and its influencing factors, followed by the descriptive statistics and discussion of the results.

\section{ECONOMIC CRIME AND TAX EVASION}

There are many different aspects to defining tax evasion. Tax evasion is a criminal act that is part of economic crime. Economic crime is an illegal act committed within a business to gain economic advantages (Appelgren, \& Sjogren, 2001: according to Sjogren, \& Skogh, 2004 p.128). In the same book, there is a distinction made between white-collar crime as a term used by Sutherland in 1949 which describes criminals in respect of their profession and characteristics, while the term occupational fraud used by ACFE in its Report to the Nations is a much wider term covering corruption, asset misappropriation, and financial statement fraud. Occupational fraud is the use of one's occupation for personal enrichment through the deliberate misuse or misapplication of the employing organizations' resources of assets (ACFE, 2020).

Economic crime consists of many different violations of the Criminal Law such as fraud in performing an economic activity, insurance fraud, embezzlement in economic activity, abuse of trust in performing an economic activity, tax evasion, failure to pay withholding taxes, abuse of the position of a responsible person, misfeasance in public procurement, abuse in the process of privatization, restricting deals, taking bribes, giving bribe, bankruptcy fraud, false bankruptcy, damaging creditors, smuggling, unauthorized trade, unauthorized manufacturing, unauthorized use of another business name, damaging business image and credit standing, counterfeiting money, revelling business secrets, forging securities, forgery, and misuse of credit cards, forgery of trademarks, making and giving others means of falsification a money laundering. So, tax evasion is only one tax scheme conducted by fraudsters.

The legal definition of tax fraud has been given in the Criminal Act of the Republic of Serbia under article 225 (Official Gazette of Republic of Serbia, No. 85/20005, corr.107/2005, corr.72/2009, 111/20009, 121/2012, $104 / 2013,108 / 2014,94 / 2016,35 / 2019$ ). Tax fraud is defined as a willful act in which fraudster has an intent to fully of partially avoid tax obligations using different schemes such as a) giving false revenue reports and facts which are correlated with the tax calculation, b) not providing facts regarding lawful income or c) concealing information or other data which are relevant for determining and calculating tax liability of that person or entity. Law on tax procedure and tax administration (Official Gazette of the Republic of Serbia 2006, 63/2006 - 61/2007, 20/2009, 72/2009 - 53/2010, 101/2011, 2/2012 - 93/2012, 47/2013, 108/2013, 68/2014, 105/2014, 91/2015, 112/2015, 15/2016, $108 / 2016,30 / 2018,95 / 2018$ and 86/2019) in heading 5, article 135 define tax evasion as a criminal offence whose consequence is tax evasion, submission of false documents, jeopardizing tax collection and tax audit, illegal sale of excise goods and other illegal activities in connection with tax evasion.

Tax evasion is defined as a managerial decision not to fully report a taxable corporate profit to reduce tax payment (Sandmo, 2005). According to this author, tax evasion is a violation of the law, while tax avoidance is an action done within the legal framework. Alm, Martinez-Vazquez and McClellan (2016) define tax evasion as ,illegal and intentional action taken by the individuals to reduce their legally due taxes...by underreporting income, overstating deductions, exemptions or credits, by failing to file appropriate tax returns or even engaging in barter... while in the corporate income tax returns firm can underreport income, overstate deductions or fail to file tax returns."

In the above-mentioned definitions, it is obvious that legal perspective and academic perspective on defining tax evasion have one common aspect -at the corporate level tax evasion is done by using different transactions. In the context of corporations, tax evasion is done by using accounting techniques of recognition and measurement of accounting items such as revenues and expenses correlated with the preparation of false accounting documents (invoices and reports) to avoid legal tax obligations. If we take into consideration indirect taxes such as VAT (valueadded taxes) those accounting transactions and its connection to the tax evasion is even more obvious (fail to register for VAT, underreport sales, present false invoices that allow a corporation to underestimate their tax liability). Therefore, all of these transactions to evade taxes are finally materialized in operating profit before taxes and influence the income tax base itself.

"Plan of income tax controls" issued by the Serbian Internal revenue Service in the year 2019 stated micro factors that are correlated with the huge risk of tax avoidance and tax evasion. This factor is the size of company measured by operating revenues and operating expenses and the \% of operating profit in the total revenue. Efficency of tax audit depends on risk factors and companies with higher operating profit are more included in the tax audit. 


\section{LITERATURE REVIEW}

There is a wide variety of academic literature regarding tax evasion. Many articles explain the interrelationship between corruption and firm tax evasion. Alm et. al (2016) demonstrate that the corruption of tax officials is a statistically and economically significant determinant of tax evasion. In the article of Alon and Hageman (2013) explanations were made regarding the correlation between firm tax compliance and corruption in 5000 firms from 22 transition economies from the former Soviet Union. Abdixhiku, Krasniqi, Pugh and Hashi (2017) found that the tax evasive behavior of firms is positively influenced by low trust in government and judicial system. Authors also find that individual businesses such as sole proprietorship and micro entities are less visible to tax authorities and are much more involved in tax evasion. Pashev (2008) makes a correlation between tax compliance of small and medium-sized entities and corruption in Bulgaria.

McGee (2008) elaborates on the opinions of tax evasion in Asia and found that in Asia women are more opposed to tax evasion than men and older people also opposed more to tax evasion than younger people. Brink and Porcano (2016) show that multiple cultural and structural variables have a direct impact on tax evasion. Androniceanu, Gherghina and Ciobănașu (2019) found that the reduction of tax evasion generates a considerable increase of the macroeconomic indicators. Đurović-Todorović, Ristić and Đorđević (2018) show that the number of tax inspectors and the number of controls with irregularities have a positive, statistically significant impact on the volume of tax evasion in Serbia.

Irianto, Sudibyo and Wafirli (2017) try to assess the influence of size, leverage, capital intensity, and profitability on tax avoidance. Size has a positive influence on the effective tax rate, while profitability, capital intensity, and leverage have no significant influence. Aminah, Chairina and Sari (2018) found that profitability and political connections have influence on tax avoidance.

Allingham and Sandmo (1972) show that probability of detection influences tax avoidance, and it is dependent on the amount of income reported. Tax authorities believe that rich individuals are most likely to evade their taxes.

Erickson, Halon and Maydew (2004) stated that publicly listed firms main incentive is to report higher earnings at the expense of paying higher taxes.

Slemrod (2007) finds that business plays a central role in the tax system of any country. There is a huge noncompliance of US businesses in the area of corporate income taxes, so-called tax gap was estimated to be 30 billion US \$ in 2001. But the estimated non-compliance rate of larger companies is lower, while for medium-sized companies tax gap is wider.
In the US tax gap is evaluated using US General Accounting office data - for small companies using IRS Taxpayer Compliance Measurement Program data, while for medium-sized companies the gap is calculated using operation audits and for large companies that are routinely investigated by the IRS calculations of tax gap or misrepresentation of tax reporting and non-compliance is directly calculated.

According to the literature review given in the previous section, the following research question is developed:

Does the tax evasion contribute more to the economic crime in Serbia than other types of fraud?

The stricter legal system and better tax administration is more capable of dealing with tax evaders therefore more people will be prosecuted for tax evasion. Since 2015 Serbian Government adopted STA transformation program for the period 2015-2020 which is supported and coordinated by the World Bank Tax administration modernization project with the main goal of improving collectiveness of taxpayers and lowering the compliance burden for taxpayers. In the year 2016 Tax administration diagnostic report was issued showing that Serbian tax administration is less automated and there is a limited accuracy of data gathered per each registrant in the tax system. That is why tax modernization is one of the key goals of the Serbian Government. We do expect that by modernization of tax system in Serbia there will be less individuals prosecuted for the tax evasion in years to come.

First tax modernization project covers a period of six years from 2018 to 2023. The first component of this project brings changes in the legal environment in terms of decreasing number of loopholes in the tax legal system. The second is human resource change and capacity building and tax operations. The third is a management modernization and digitalization or ICT system building. The fourth component is a project management and change management. Reengineering of the existing business processes will be done during this project and activities included are: tax registration, tax accounting and audit control. In the year to come, we strongly believe that the tax system will be efficient and tax audits will help to find tax evasion areas, to decrease loopholes in those areas and to prosecute less individuals for this type of crime. Tax modernization reform should affect fraudsters in Serbia not to commit this type of crime and its contribution to the economic crime percentage in the future should be lower. 


\section{METHODOLOGY OF THE RESEARCH}

Five years of observations of the tax evasion and economic crime data are included in this paper. Data are obtained from by the Statistical Office of the Republic of Serbia.

Internal validity is the extent to which we achieve matching the structure of research design with the unambiguous conclusions. In this study, we use secondary sources of data that we think match the needs of our research. There is a low risk of bias or error in the research results because the secondary data source can be determined to be reliable (Statistical office of the Republic of Serbia).
The external validity of the research in terms of generalizing the results beyond the sample is limited. We took the sample of individuals prosecuted for tax evasion and economic crime in from Serbia and we draw conclusions that are country, cultural, and socio specific.

\section{RESULTS AND DISCUSSION}

In Table 1 results regarding the comparison between prosecuted economic crime and prosecuted tax evasion are given.

Table 1. Comparison between prosecuted economic crime and prosecuted tax evasion in Serbia in the period 2014-2018

\begin{tabular}{llll}
\hline Year & $\begin{array}{l}\text { Prosecuted individuals for } \\
\text { economic crime }\end{array}$ & $\begin{array}{l}\text { Prosecuted individuals for } \\
\text { tax evasion }\end{array}$ & $\begin{array}{l}\text { \% of tax evasion criminal } \\
\text { acts in total economic crime }\end{array}$ \\
\hline 2014 & 2748 & 788 & 28,67 \\
\hline 2015 & 2570 & 778 & 30,27 \\
\hline 2016 & 2375 & 643 & 27,07 \\
\hline 2017 & 2015 & 649 & 32,2 \\
\hline 2018 & 1683 & 967 & 57,45 \\
\hline Total & 11391 & 3825 & $/$ \\
\hline
\end{tabular}

Source: Statisticial office of the Republic of Serbia

Taking into consideration only economic crime it is obvious from Table 1 that number of individuals prosecuted for this type of crime decrease from $2014-2018$. The number of individuals prosecuted for tax evasion decreases from 2014-2017 but shows a significant growth in the year 2018.
According to Table $1 \%$ of individuals prosecuted for tax evasion increase from $28,67 \%$ in the year 2014 up to $57,45 \%$ in the year 2018. Based on the results we can conclude that tax evasion is considered to be one of the most important criminal acts within the economic crime in Serbia in the 5 year period taken in observation.

Table 2. Prosecuted individuals for the economic crime in the period 2014-2018

\begin{tabular}{lll}
\hline Year & $\begin{array}{l}\text { Prosecuted individuals for } \\
\text { economic crime }\end{array}$ & $\begin{array}{l}\text { Index } \\
\text { (Base year 2014=100) }\end{array}$ \\
\hline 2014 & 2748 & 100 \\
\hline 2015 & 2570 & 93,52 \\
\hline 2016 & 2375 & 86,42 \\
\hline 2017 & 2015 & 73,32 \\
\hline 2018 & 1683 & 61,24 \\
\hline Total & 11391 & - \\
\hline
\end{tabular}

Source: Statisticial office of the Republic of Serbia and authors' own calculation

Table 2 shows that number of individuals prosecuted for economic crime constantly decreases compared with the base year (2014). In the year 2015 index of individuals prosecuted for this type of crime is 93,5 or it is a decrease of $6,48 \%$ compared with the base year. In the year 2016 index is 86,42 or it is for $13,58 \%$ lower number of indi- viduals prosecuted than those in the base year. In the year 2017, this index is even lover and it is 73,32 meaning that the number of individuals prosecuted for an economic crime is $26,68 \%$ lower than in the base year. The same conclusion can be drawn for 2018 where the number of individuals prosecuted is $38,76 \%$ lower than in the year 2014 . 
Therefore, modernizing the legal system and preventive measures in the period 2014-2018 were effective in terms of reducing the number of people willing to commit this type of crime. If individuals are more aware of being caught they will less use their abilities to commit this type of crime.

Table 3. Prosecuted individuals for the tax evasion in the period 2014-2018

\begin{tabular}{lll}
\hline Year & $\begin{array}{l}\text { Prosecuted individuals for } \\
\text { tax evasion }\end{array}$ & $\begin{array}{l}\text { Index } \\
\text { (Base year 2014=100) }\end{array}$ \\
\hline 2014 & 788 & 100 \\
\hline 2015 & 778 & 98,73 \\
\hline 2016 & 643 & 81,59 \\
\hline 2017 & 649 & 82,36 \\
\hline 2018 & 967 & 122,71 \\
\hline Total & 3825 & - \\
\hline
\end{tabular}

Source: Statisticial office of the Republic of Serbia and authors' own calculation

Table 3 shows the number of individuals prosecuted for the tax evasion and respective index numbers. It is shown that number of individuals prosecuted decrease in the year 2015 for only $1,27 \%$ which is much lower than individuals prosecuted for the economic crime in the same period, showing that tax evasion is much more rigid crime component than other types of economic crime. In the year 2015 decrease is $18,41 \%$ compared with the base year (2014), while in the year 2016 decrease is $17,64 \%$. The last year taken into considerations shows an extreme and abrupt change in the number of individuals.
The index is 122,71 meaning that more individuals are caught for tax evasion in this year than in the base year. The number increased for $22,71 \%$, implying that preventive measures and efficient tax system started to show its effects in this year.This could be a result of all measures applied in the whole 5 year period in questions whose effects accumulated in the year 2018, so that is why large increase is shown. Serbia started to change its tax administration by educating more tax officials since the year 2014. This could also contributed to the results for the year 2018 .

Table 4. Descriptive statistics of Economic crime and Tax evasion in Serbia in the period 2014-2018

\begin{tabular}{llllll}
\hline & N & Minimum & Maximum & Mean & Std. Deviation \\
\hline $\begin{array}{l}\text { Economic } \\
\text { crime }\end{array}$ & 5 & 1683 & 2748 & 2278.20 & 429.758 \\
\hline Tax evasion & 5 & 643 & 967 & 765.00 & 132.138 \\
\hline $\begin{array}{l}\text { Valid N } \\
\text { (listwise) }\end{array}$ & 5 & & & & \\
\hline
\end{tabular}

Source: Authors' own calculations

Table 4 shows that in a five year period a minimum number of individuals prosecuted for an economic crime is 1683 and a maximum of 2748 , while the mean number is 2278 . The standard deviation is 430 individuals, showing a large deviation from the sample mean.

For tax evasions situation is different. Mean number of individuals prosecuted is 765 while standard deviation is 132. Fluctuating number of individuals prosecuted for both types of crime support the idea of efficient tax administration in Serbia in the above mentioned period of time.

Both standard deviations are high implying that 5-year period taken into consideration in this descriptive analysis shows large variations in observing variables.

\section{CONCLUSION}

The research question has been confirmed by the data showing that tax evasion significantly contributes to the economic crime in Serbia in the last 5 years (the period from 2014 to 2018). According to the data, prosecuted individuals for tax evasion contributed in 2014 with $28.67 \%$ of total prosecuted economic crime acts, and then it rose to $57.45 \%$ in the year 2018 . Therefore, by showing a double increase in the mentioned period, conclusion regarding more efficient legal system and tax administrative system can be drawn. Other researchers show that tax rate, audit probability and fine influence tax evasion (Kiri, 2016). 
Allingham and Sandmo (1972) show that the increase in the probability of detection increase the reported income of companies. Tax administration modernization reforms started in 2015 in Serbia. Data in the year 2018 supported the idea that reform is efficient because $50 \%$ more individuals are prosecuted for tax evasion than in the year 2014. So, statistics confirms that reform has its effects in building the capacity of tax administration and decreasing loopholes in the legal system.

\section{ACKNOWLEDGMENT}

This paper is part of the project No. 22010083 entitled "Experience sharing of Visegrad countries to tax avoid activity" financed by the International Visegrad Fund.

\section{LITERATURE}

ACFE. (2020) Report to the Nations, Global Headquarters, Austin, Texas.

Allingham, M. G., \& Sandmo, A. (1972). Income tax evasion: A theoretical analysis. Journal of public economics, 1(3-4), 323-338.

Abdixhiku, L., Krasniqi, B., Pugh, G., \& Hashi, I. (2017). Firmlevel determinants of tax evasion in transition economies. Economic Systems, 41(3), 354-366.

Abdixhiku, L. (2013). Determinants of business tax evasion in transition economies. Doctoral thesis, Staffordshire University.http://eprints.staffs.ac.uk/id/eprint/1962

Alm, J., Martinez-Vazquez, J., \& McClellan, C. (2016). Corruption and firm tax evasion. Journal of Economic Behavior \& Organization, 124, 146-163.

Alon, A., \& Hageman, A. M. (2013). The impact of corruption on firm tax compliance in transition economies: whom do you trust? Journal of Business Ethics, 116(3), 479-494

Aminah, A., Chairina, C., \& Sari, Y. Y. (2018). The Influence of Company Size, Fixed Asset Intensity, Leverage, Profitability, and Political Connection to Tax Avoidance. AFEBI Accounting Review, 2(02), 30-43.

Androniceanu, A., Gherghina, R. \& Ciobănaşu, M. (2019). The interdependence between fiscal public policies and tax evasion, Administratie si Management Public, 32, 32-41.

Brink, W. D., \& Porcano, T. M. (2016). The impact of culture and economic structure on tax morale and tax evasion: A country-level analysis using SEM, p. 87-123. In Advances in Taxation, Volume 23. Emerald Group Publishing Limited.

Erickson, M., Halon, M. \& Maydew, E. (2004). How much firms pay for earnings that do not exist? Evidence of taxes paid on allegedly fraudulent earnings. The Accounting Review, 29 (2), 387- 408.
Đurović Todorović, J. , Đorđević, \& M., Ristić, M. (2018). Estimating the determinants of tax evasion using empirical data, Proceedings of the Faculty of Economics in East Sarajevo DOI: 10.7251/ZREFIS1716011D

Irianto, B. S., Sudibyo, Y. A., \& Wafirli, A. (2017). The influence of profitability, leverage, firm size and capital intensity towards tax avoidance. International Journal of Accounting and Taxation, 5(2), 33-41.

Kiri, N. (2016) Factors affectint tax evasion, International Journal of Economics, commerce and Management, 4(2), 804-811.

McGee, R.W. (2008). Opinions of tax evasion in Asia, 309-321. In: McGee, R. W. (Ed.). (2008). Taxation and public finance in transition and developing economies. Springer Science \& Business Media.

Pashev, K. V. (2008). Monitoring of tax corruption in transition economies: Evidence from Bulgaria. In Taxation and public finance in transition and developing economies (pp. 321-362). Springer, Boston, MA.

Ranđelović, S. (2015). Tax design-tax evasion relationship in Serbia: New empirical approach to standard theoretical model. Industrija, 43(1), 73-89.

Savić, G., Dragojlović, A., Vujošević, M., Arsić, M., \& Martić, M. (2015). Impact of the efficiency of the tax administration on tax evasion. Economic research-Ekonomska istraživanja, 28(1), 1138-1148.

Slemrod, J. (2007) Cheating ourselves - the Economy of tax evasion, Journal of Economic Perspectives 21(1), 25-48.

Sandmo, A. (2005). The theory of tax evasion: A retrospective view, National tax journal ,58(4), 643-663.

Southeast Europe Leadership for Development and Integrity - SELDI. (2016). Hidden economy and Good Governance in Southeast Europe. Regional Assessment Report . Center for the study of Democracy, Sofia, Bulgaria.

Sjogren, \& Skogh (2004). New perspectives of economic crime, Cardiff University.

The Serbian Internal revenue Service (2019). Plan of income tax controls [Godišnji plan poreske kontrole]. 